\title{
Estimation of Post-Harvest Losses of Fish Transported Using Ice-chilled Carrier Boats from High Seas Pocket 1
}

\author{
Ulysses M. Montojo ${ }^{1 \star}$, Virginia H. Delos Santos ${ }^{1}$, Camille M. Narida ${ }^{1}$, Ivy Y. Febreo ${ }^{1}$, Deserie M. Peralta ${ }^{1}$ \\ Riza Jane S. Banicod ${ }^{1}$, and Omar M. Sabal ${ }^{2}$
}

${ }^{1}$ Fisheries Post Harvest Research and Development Division-Fish Handling and Processing Section, National Fisheries Research and Development Institute, Quezon City, Philippines

${ }^{2}$ Bureau of Fisheries and Aquatic Resources, Regional Field Office No. X11, Koronadal City, South Cotabato, Philippines

\begin{abstract}
A B S T R A C T
Access of Philippine traditional fresh/ice-chilled seining vessels to High Seas Pocket 1 (HSP-1) lessens fishing pressures in the Philippine Exclusive Economic Zone where juvenile oceanic tunas are more likely to be found. However, catch landed by carrier boats from HSP-1 were observed to be of reduced quality, thus eliciting lower market value. The present study was conducted to evaluate the efficiency of icechilled carrier boats by generating data on the magnitude of post-harvest losses incurred in landed catch from HSP-1. Exploratory Fish Loss Assessment Method and Questionnaire Loss Assessment Method were used to estimate quality losses. Landed catch of ice-chilled carrier boats from HSP-1 recorded an estimated loss of $17.25 \%$. Key players incurred an estimated financial loss amounting to PHP 223 million (USD 4.3 million). Low quality catch commonly sold as raw materials for canning, smoking, and fishmeal processing entail cheaper prices, thus regarded as losses. A positive correlation was established between fishing duration and losses. Results indicate that the current preservation technique in carrier boats could induce quality deterioration in fish given the long distances and transit times involved. Thus, the use of carrier boats with freezing system should be allowed in HSP-1 to sufficiently preserve the quality of the catch. This will reduce losses in post-harvest fisheries, thereby increasing the potential income of HSP-1 players.
\end{abstract}

*Corresponding Author: ulyssesmontojo@gmail.com Received: November 15, 2019

Accepted: May 8, 2020
Keywords: Post-Harvest Losses, High Seas Pocket 1, Tuna, QLAM, EFLAM

\section{I N T RODUCT ION}

$\mathrm{T}$ The Philippine tuna industry contributes positively to the economy through direct revenues and employment opportunities (BFAR 2003; WCPFC 2016a). According to Bureau of Fisheries and Aquatic Resources, tuna has continued to dominate the Philippine fishery export in terms of volume and value since 2004 (BFAR 2018). In 2017, the country exported 305,466 metric tons (MT) of fresh/chilled/frozen, smoked/dried, and canned tuna products amounting to USD 504 million (BFAR 2017). The total production of oceanic tuna such as skipjack, yellowfin tuna, and bigeye tuna were recorded at $382,160.611$ MT in both municipal and commercial fisheries sectors (PSA 2017). Tanangonan et al. (2018) reported that approximately $6.33 \%$ or 24,203 MT of the total production in 2017 was caught in High Seas Pocket 1 (HSP-1).

HSP-1 is the area of high seas bounded by the Exclusive Economic Zones (EEZs) of the Federated States of Micronesia to the north and east, Republic of Palau to the west, and Indonesia and Papua New Guinea to the south (WCPFC 2013; BFAR-NFRDI 2012). After its closure in 2010, displaced fleets were forced to catch juvenile oceanic tunas in the Philippine EEZ. The Philippines appealed for the re-opening of HSP-1 as it negatively impacted the production of tuna in the country (BFAR 2018). Its lobby succeeded when the Western and Central Pacific Fisheries Commission 
(WCPFC 2012) adopted the Conservation Management Measure 2011-01 in 2012. Philippine traditional fresh/ice-chilled seining vessels were given access to HSP- 1 as a Special Management Area under certain conditions. These include limit to 36 catcher fishing vessels, mandatory use of Vessel Monitoring System or Automatic Location Communicator, and regional observer coverage (BFAR 2013; Tanangonan et al. 2018). Moreover, the operation should be conducted only for nine months prohibiting setting of fish aggregating device during the months of July, August and September (WCPFC 2016b).

Access to HSP-1 lessens fishing effort in the Philippine EEZ where juvenile tunas are more likely to be found (BFAR 2013). However, catch preservation has been challenged by the complexity of the fishing ground in terms of distance, area, and fishing duration. Catch landed by carrier boats from HSP-1 were observed to be of reduced quality given the long distances and transit times involved (USAID 2017a). Deterioration of fish quality prior to landing will negatively affect its market value; hence, considered as losses in post-harvest fisheries. Post-harvest losses are of major concern as it affect not only the income of the fisherfolk but also the food security in the country (Diei-Ouadi and Mgawe 2011).

The use of ice-chilled storage facilities in carrier boats may not suffice the lengthy fishing operations in HSP-1, thus could potentially result to substantial post-harvest losses. To evaluate the efficiency of ice-chilled carrier boats, the present study focused on the generation of actual data on the magnitude of post-harvest losses incurred in landed catch from HSP-1.

\section{MATERIALS AND METHODS}

\subsection{Data Collection}

Assessment method was based on the Manual for Assessing Post-Harvest Fisheries Losses by Ward and Jeffries (2000). In the present study, Exploratory Fish Loss Assessment Method (EFLAM) was used during the inception to generate initial data. Stakeholder group discussion was conducted with representatives from BFAR Regional Field Office No. XII, BFAR-Fisheries Observer Program (FOP), SOCSKSARGEN Federation of Fishing \& Allied Industries, Inc., Philippine Fisheries Development Authority, and HSP-1 catcher vessel company owners. Data concerning the estimate loss levels, types of losses occurring, and variables affecting losses were also obtained from the log sheets, catch origin landing declaration, captain/mate's transfer certificate, and stowage plan of the company owners from JanuaryJune 2017 and October-December 2017.

The Questionnaire Loss Assessment Method (QLAM), which is based on a formal survey approach was used during the assessment from October 2018 to June 2019. Formulated questionnaires (Figure 1) were edited and finalized during the conduct of EFLAM. Trained enumerators were assigned to interview boat crew members, brokers, and middlemen who were knowledgeable about the fishing practices and trading information.

\subsection{Sample Size}

Sample size was based on the $30 \%$ rule of thumb sampling (Ward and Jeffries 2000). Thirty two (32) catcher vessels in HSP-1 were identified based from BFAR FOP data. Sample size was set, but not limited to 13 landings or $30 \%$ of the catcher vessels. Enumerators gathered information six times a week from all landed carriers boats in General Santos Fish Port Complex (GSFPC).

\subsection{Species}

Species assessed were mostly comprised of oceanic tuna including yellowfin tuna Thunnus albacares, bigeye tuna Thunnus obesus, and skipjack Katsuwonus pelamis, and other species such as mackerel scad Decapterus macarellus, mackerel tuna Euthynnus affinis, frigate tuna Auxis thazard, bullet tuna Auxis rochei, and big eye scad Selar crumenophthalmus. These were caught by purse seine and ring net vessels in HSP-1.

\subsection{Computation of Losses}

Only quality loss was considered and computed since there were no physical and market force losses observed in the transport. Computation was based on the prevailing market value of the commodity. Price reduction of the catch from its prevailing price was considered as the total postharvest loss.

Quality loss refers primarily to the monetary loss (Equation 1) caused by lowering of the commodities' price due to the changes brought by spoilage and presence of defects such as skin loss, laceration, and burst belly. It is the difference between the best price or the potential value of the species at 
its best quality, and the reduced price at which the inferior commodity was sold. Equivalent volume of these monetary loss was obtained using equation 2 .

(Equation 1)

$$
V_{T Q L}=\sum_{i=1}^{n}\left(B P r_{i}-R P r_{i}\right) \times S Q L_{i}
$$

(Equation 2)

$$
T Q L=\sum_{i=1}^{n} \frac{\left(B P r_{i}-R P r_{i}\right)}{B P r_{i}} \times S Q L_{i}
$$

where:

VTQL is the total value of quality loss (PHP);

$\mathrm{n}$ is the number of respondents;

$\mathrm{BPr}$ is the best price of commodity per $\mathrm{kg}$ (PHP);

$\mathrm{RPr}$ is the reduced price of the commodity per $\mathrm{kg}$ (PHP);

SQL is the volume subjected to quality loss of each respondent $(\mathrm{kg})$; and

TQL is the total quality loss $(\mathrm{kg})$

Percentage loss:

$$
\text { (Equation 3) }
$$

$$
\% \text { LosS }=\frac{T Q L}{T C A} \times 100
$$

where:

TQL is the total quality loss ( $\mathrm{kg}$ );

TCA is the total catch assessed $(\mathrm{kg})$.

Financial loss was computed based on the best price of the commodities assessed. The best price was based on the prevailing price standards of the catch sold in local markets. However, in instances wherein the best price was not given, interpolation formula (Equation 4) was used. Foreign exchange conversion average rates of Philippine Pesos to US Dollars was obtained from the data of Bangko Sentral ng Pilipinas (www.bsp.gov.ph).

Interpolation Formula for Best Price Computation

$$
\text { (Equation 4) } \quad \frac{S_{1}}{B P r}=\frac{S_{2}}{P_{2}}>\quad B P r=\frac{S_{1} P_{2}}{S_{2}}
$$

where:

$\mathrm{BPr}$ is the best price of commodity per $\mathrm{kg}$ (PHP); $\mathrm{S} 1$ is the size of commodity with the unknown potential or best price in $\mathrm{kg}$;

S2 is the size of commodity with the known price in $\mathrm{kg}$ $\mathrm{P} 2$ is the price of the commodity with size S2 per kg (PHP).

\subsection{Data Analysis}

Descriptive statistics was used to quantitatively describe and summarize features of the collected data. Microsoft excel was used to exemplify the values obtained from the assessment. These include quantitative and financial losses, catch composition and losses, and catch distribution. Moreover, regression analysis was performed to determine the correlation between post-harvest losses and fishing duration of the carrier boats.

\section{RESULTSAND DISCUSSION}

\subsection{Quantitative and Financial Loss}

Out of 12,725.33 MT catch assessed from 216 recorded landings, $17.25 \%$ or equivalent to $2,194.49$ MT was recorded as loss. The estimated quality loss was mainly due to the presence of defects such as lacerated flesh, skin loss, or burst belly. Monthly losses ranged from $12.61 \%$ to $24.29 \%$ with maximum loss incurred during February. Percentage loss varies every month irrespective of the volume of catch assessed. Despite the least volume of catch assessed, highest percentage loss was recorded during February. Roughly $85.9 \%$ of the losses incurred in February were skipjack, followed by yellowfin tuna (13.7\%) and bigeye tuna (0.4\%). Tanangonan et al. (2018) reported that the average size of skipjack were smaller compared to yellowfin and bigeye tuna. Smaller size tunas are more susceptible to physical damage during stacking and unloading of catch. Insufficient preservation of physically damaged fish hastens the rate of spoilage resulting to quality loss. The data of the latter also shows that the highest volume of catch from HSP-1 for 2017 were recorded during October and November. The three-month closed season in HSP-1 was just lifted during these months. Contrary to the data of Tanangonan et al. (2018), volume of catch assessed during October 2018 was lower compared to the succeeding months due to the least number (17) of landed carrier boats assessed. The volume of catch assessed was reliant on the recorded landings of carrier boats in GSFPC.

Key players incurred an estimated financial loss amounting to PHP 223 million (USD 4.3 million). Highest financial loss valued at PHP 41.5 million was recorded during January. The corresponding financial loss varies depending on the prevailing price recorded every assessment, thus percentage loss was not directly proportional to financial loss. In a similar study conducted by USAID (2017b), roughly $20 \%$ of 
Table 1. Estimated annual post-harvest losses

\begin{tabular}{lllllll}
\hline Month & $\begin{array}{l}\text { No. of } \\
\text { carrier boats } \\
\text { assessed }\end{array}$ & $\begin{array}{l}\text { Total Catch } \\
\text { Assessed } \\
(\mathbf{M T})\end{array}$ & $\begin{array}{l}\text { Quality Loss } \\
(\mathbf{M T})\end{array}$ & $\begin{array}{l}\text { Percentage } \\
\text { Loss (\%) }\end{array}$ & $\begin{array}{l}\text { Financial } \\
\text { Loss (Php) }\end{array}$ & $\begin{array}{l}\text { Financial } \\
\text { Loss (US\$) }\end{array}$ \\
\hline \hline July $^{*}$ & - & - & - & - & - & - \\
August $^{*}$ & - & - & - & - & - & - \\
September $^{*}$ & - & - & - & - & - & - \\
October & 17 & 986.31 & 146.29 & 14.83 & $12,688,700$ & $242,048.68$ \\
November & 23 & 1233.64 & 210.85 & 17.09 & $18,218,303$ & $347,530.97$ \\
December & 20 & 1175.46 & 171.01 & 14.55 & $16,549,455$ & $315,696.15$ \\
January & 31 & 1748.28 & 298.33 & 17.06 & $41,578,996$ & $793,157.78$ \\
February & 18 & 966.63 & 234.80 & 24.29 & $31,176,626$ & $594,722.95$ \\
March & 32 & 1957.18 & 317.38 & 16.22 & $30,135,606$ & $574,864.53$ \\
April & 27 & 1708.30 & 309.79 & 18.13 & $29,678,422$ & $566,143.33$ \\
May & 26 & 1278.07 & 161.15 & 12.61 & $14,360,423$ & $273,938.34$ \\
June & 22 & 1671.46 & 344.89 & 20.63 & $28,805,988$ & $549,500.84$ \\
\hline \hline TOTAL & $\mathbf{2 1 6}$ & $\mathbf{1 2 , 7 2 5 . 3 3}$ & $\mathbf{2 , 1 9 4 . 4 9}$ & $\mathbf{1 7 . 2 5}$ & $\mathbf{2 2 3 , 1 9 2 , 5 1 9}$ & $\mathbf{4 , 2 5 7 , 6 0 3 . 5 7}$ \\
\hline
\end{tabular}

${ }^{\star}$ Closed fishing season

the catch from purse seine operations in HSP-1 in 2014 were processed as smoked and fishmeal, thereby incurring an estimated PHP 380 million financial loss. Karningsih et al. (2018) identified the possible risks in Indonesian Tuna supply chain, which include reduced quality of fish due to unavailability of cold storage facilities in fishing vessels. In addition, the latter conferred that low market value for tuna could lead to potential loss of revenue for fisherfolk, thus affecting their perspective towards fishing. Fisherfolk has come up with various strategies such as borrowing money or increasing fishing effort to cope up with monetary losses. However, technical interventions are needed as a response to the socio-economic problems brought by post-harvest losses (Akande and Diei-Ouadi 2010). Post-harvest losses limit fisherfolk's capability to diversify their income through loss of potential revenue. According to Diei-Ouadi et al. (2015), development practitioners are committed to improving the livelihoods of key players (fishers, traders, and processors) through reduction of postharvest losses. Cost-effective loss reduction is essential not only to improve food security but also to augment the income of the fisherfolk for poverty alleviation.

\subsection{Catch Composition and Losses}

Majority of the catch assessed was composed of skipjack K. pelamis (67.94\%) and yellowfin tuna $T$. albacares (27.06\%). Bigeye tuna T. obesus constituted $1.5 \%$ of the catch, while the remaining $3.5 \%$ was comprised of mixed species including mackerel scad D. macarellus, mackerel tuna E. affinis, frigate tuna A. thazard, bullet tuna A. rochei, and bigeye scad $S$. crumenophthalmus (Figure 2). These oceanic tuna species are the primary tuna stocks targeted by the main Western and Central Pacific Ocean industrial fisheries and the main concern of the WCPFC. 


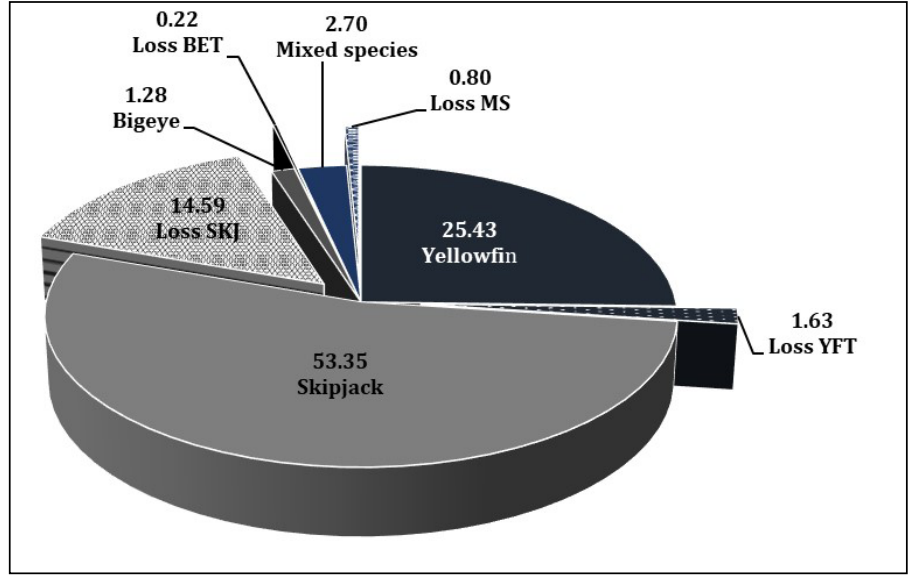

Figure 2. Catch composition and losses

Highest loss was recorded in skipjack, which comprised $14.59 \%$ or $1,856.84$ MT of the total catch assessed. It was followed by yellowfin tuna at $1.63 \%$, mixed species at $0.80 \%$, and bigeye tuna at $0.22 \%$. Based on the results, it can be inferred that losses incurred from each species were proportional to the catch composition. Bulk of the species caught was skipjack, thus it incurred the highest percentage loss. Skipjack tuna comprised $58.2 \%$ of the catch of purse seiners in the Philippines (Bigelow et al. 2016).

Losses discussed in the preceding paragraph were computed based on the total volume of catch assessed. Estimation of losses by species showed that $22.80 \%$ of the total volume of skipjack were recorded as loss. Mixed species obtained $21.40 \%$ loss, while bigeye and yellowfin tuna incurred $14.53 \%$ and $6.05 \%$ losses, respectively. As discussed earlier, skipjack and mixed species caught in HSP-1 were of smaller sizes, thus more susceptible to physical damage. Tanangonan et. al. (2018) reported that the length of skipjack ranged from 12.00 to $90.00 \mathrm{~cm}$ with an average length of $38.41 \mathrm{~cm}$. Mackerel scads, which dominated the mixed species, has an average length of $24.61 \mathrm{~cm}$ with minimum and maximum length of $10.00 \mathrm{~cm}$ and $57.00 \mathrm{~cm}$, respectively. On the other hand, yellowfin tuna has an average length of 41.91 $\mathrm{cm}$ and can reach up to $145 \mathrm{~cm}$, while bigeye tuna has an average length of $51.28 \mathrm{~cm}$ with maximum length of $125 \mathrm{~cm}$. Minimal loss was obtained in larger tunas such as yellowfin and bigeye as these species are more likely to induce physical damage to smaller size tunas during stacking and unloading.

\subsection{Catch Distribution}

Catch from HSP-1 were distributed in the local markets, canneries, smoked processing, and fishmeal processing (Figure $3)$. Majority of catch were distributed in canneries (59.42\%) and local markets (38.03\%). The remaining $2.31 \%$ and $0.24 \%$ were distributed in smoked and fishmeal processing, respectively. Prevailing price was recorded in catch distributed in local markets. Catch of reduced quality were commonly sold as raw materials for canning, smoking, and fishmeal processing which entail cheaper prices, thus regarded as losses. Catch distributed in smoked processing has lower market value than in canneries, while fishmeal has the least value among the four distribution chain. According to Hipolito and Vera (2006), majority of catch from purse-seine fleet are cannery-grade quality intended for processing, thus canneries in General Santos City, Philippines are reliant on purse seine fishers for raw supply of tuna. Purse-seine vessels that were unable to carefully handle the catch due to huge volume per operation have lower quality of catch commonly processed into canned goods (Bayliff 2016).

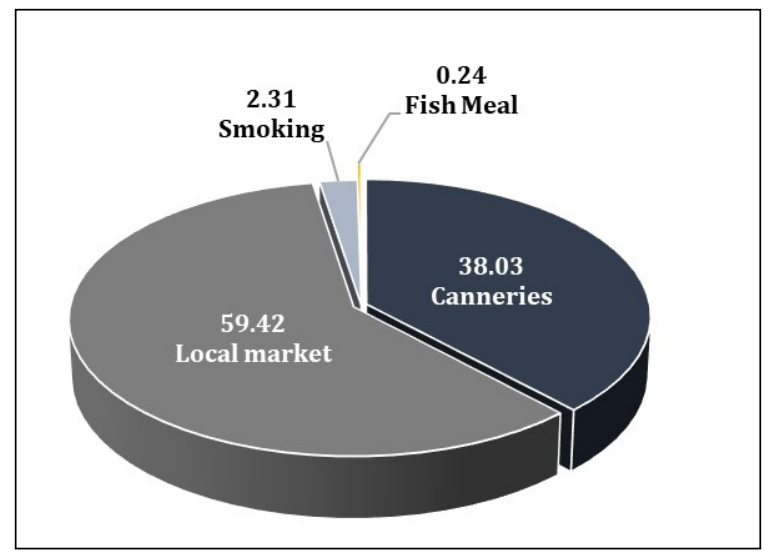

Figure 3. Catch distribution of fish from HSP-1 fish carrier boats

\subsection{Fishing Duration and Losses}

Travel duration from fishing port to HSP-1 or vice versa may take five to ten days. Fishing duration started when the carrier boats departed from the fish port until they landed. Regression analysis showed a positive correlation between fishing duration and losses. Losses tend to increase with increasing fishing duration. Majority of carrier boats conducted fishing activities from 21 to 30 days and may extend for 


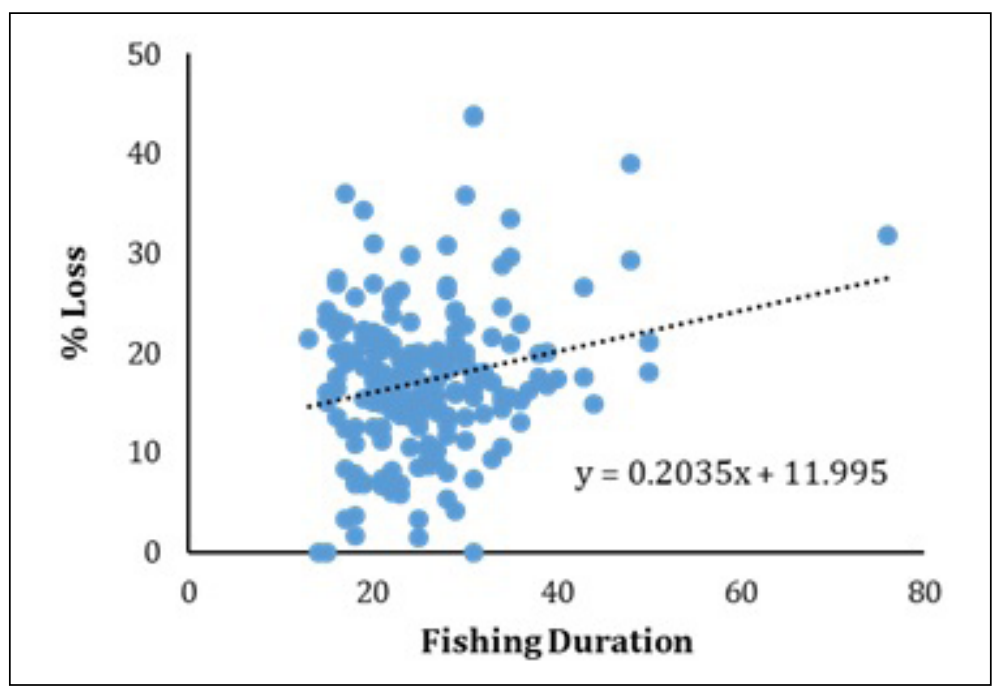

Figure 4. Regression of Losses and Fishing Duration technique during prolonged fishing period was one of the many factors that could induce post harvest losses (Getu et al. 2015).

As mentioned earlier, spoilage can be retarded by chilling, but deteriorative changes still occur at a slower rate. Continuous bacterial and enzymatic activities could induce microbiological, chemical, physical, and sensory changes in fish flesh during chilled storage. Fish stored in ice-chilled compartments are susceptible to spoilage brought by psychrotrophic bacteria, which can easily thrive at low temperatures. Scrombroid fish such as tuna are known to contain high levels of free-histidine, which

more than two months. Tuna fishing operators tend to increase their fishing effort to meet the demands of canneries for export market. Lengthy fishing operations which usually last for more than two weeks could induce quality deterioration in fish (Vera and Hipolito 2006).

USAID (2017a) pointed out that dependence on ice-chilling as preservation technique could lead to fish quality loss especially when fishing in HSP-1. Espejo-Hermes (2004) defined chilling as lowering of temperature close or just below the initial freezing point typically between $-1.10^{\circ} \mathrm{C}$ to $2.20^{\circ} \mathrm{C}$ to considerably retard the rate of spoilage. Preservation of fish by refrigerated seawater is common in larger vessels with longer fishing duration. The freezing point of seawater is around $-1.50^{\circ} \mathrm{C}$, thus ideal for rapid chilling of fish. For tropical countries, the ideal waterice-fish ratio is 1:2:6 (Shawyer and Medina-Pizzali 2003). Soaking of fish at temperature ranging from $-1.00^{\circ} \mathrm{C}$ to $2.00^{\circ} \mathrm{C}$ throughout the fishing period will prolong the shelf life of the commodity (Nair 2002). However, according to Johnston et al. (1994), storage of fish in ice-chilled can only last for maximum period of two weeks. The current preservation technique in carrier boats may not suffice the lengthy fishing operations in HSP-1. Each carrier boat has different turnaround time to port, which varies between two weeks to one month. In extreme cases, it could extend up to two months depending on the number of sets needed to fill their holds. Some carrier boats opt to stay longer in HSP-1, especially when there is scarcity of catch. This may result to quality deterioration of the first batch of unloaded catch. Insufficient preservation can be converted to histamine through bacterial action. Psychrotolerant histamine-producing bacteria Morganella morganii and Photobacterium phosphoreum can be found in chilled fish stored at $2.00^{\circ} \mathrm{C}$ (Nalan and Pinar 2015; Emborg et al. 2005). Results of GarciaTapia et al. (2013) revealed that M. morganii was the most active histamine-producing bacteria in yellowfin tuna. Aforementioned studies clearly demonstrate that adequate preservation and temperature control are critical to inhibit quality deterioration in fish.

Freezing has long been considered as an efficient way of preserving commodities for longer periods (Sampels 2014). Espejo-Hermes (2004) specified that this method will keep the fish for several months without discernable changes in quality. In other countries such as Japan, Korea, and Taiwan, fishing vessels enable the use of freezer holds with ultra-low temperatures $\left(-40.00^{\circ} \mathrm{C}\right.$ to $\left.-45.00^{\circ} \mathrm{C}\right)$ to preserve the quality of the catch during distant-water fishing (Havice et al. 2019). Fishing operation using freezer and refrigerated holds can last from 1.5 up to 3 months per trip (Dickinson 1973). Goulding (2001) recommended that tuna should be kept at $-18.00^{\circ} \mathrm{C}$ or below during long distance transport. On the other hand, Burgaard (2010) suggested that tuna should be stored at $-30.00^{\circ} \mathrm{C}$ to preserve its quality for up to 3 months.

In the Philippines, fish loss is identified as one of the two core problems in post-harvest fisheries (BFAR 2015). Moreover, one of the objectives of the National Tuna Management Plan is to reduce postharvest losses to $15 \%$ in five years (BFAR 2018). As compliance to Article 11.1.8 of the Code of Conduct 
for Responsible Fisheries of FAO (1998), improvement of the current fish preservation technique and facilities in carrier boats are necessary to improve the quality of catch landed from HSP-1 to reduce post-harvest losses.

\section{C O N C L US I O N}

Fish transported by ice-chilled carrier boats from HSP-1 recorded an estimated loss of $17.25 \%$ or equivalent to PHP 223 million financial loss. Results of this study indicate that the current preservation technique in carrier boats could induce quality deterioration in fish due to lengthy fishing operations in HSP-1. Thus, the use of carrier boats with freezing system should be allowed in HSP-1 to sufficiently preserve the quality of the catch. This will reduce losses in post-harvest fisheries; thereby, increasing the potential income of HSP-1 players.

\section{ACKNOWLED G EMEN T}

This study was funded by the National Fisheries Research and Development Institute as a sub-component project of Reduction of Post-Harvest Losses Program. The authors would like to thanks the management of BFAR Region Field Office XII; General Santos Fish Port Complex; SOCSKSARGEN Federation of Fishing and Allied Industries, Inc.; Fishing Company Operators and staff of HSP1 catcher vessels; BFAR-Philippine Fisheries Observer Program; and to all industry players who participated during meetings, group discussions and data collections.

\section{R E F E R E N C E S}

Akande G, Diei-Ouadi Y. 2010. Post-harvest losses in small-scale fisheries: Case studies in five subSaharan African countries. [Internet]. FAO Fisheries and Aquaculture Department. Rome: FAO Fisheries Technical Paper 550; [cited 2020 Jan 25]. Available from: http://www.fao.org/3/ i1798e/i1798e.pdf.

Bayliff WG. 2016. The fisheries for tunas in the eastern Pacific Ocean. In: Benetti DD, Partridge GJ, Buentello A. Advances in Tuna Aquaculture. Elsevier Inc. Amsterdam. p 21-41.

[BFAR] Bureau of Fisheries and Aquatic Resources. 2003. National Tuna Report Philippines. 16th Meeting of the Standing Committee on Tuna and Billfish in Queensland, Australia; July 9-19, 2003. [Internet]. Available from: https://pacificdata.sprep.org/system/files/nfr_philippines. pdf.

[BFAR] Bureau of Fisheries and Aquatic Resources. 2013. Regulations and implementing guidelines on group tuna purse seine operations in High Seas Pocket Number 1 as a Special Management Area. [Internet]. Bureau of Fisheries and Aquatic Resources; [cited 2020 Mar 23]. Available from: https://www.bfar.da.gov.ph/ LAW?fi=409.

[BFAR] Bureau of Fisheries and Aquatic Resources. 2015. Comprehensive National Fisheries Industry Development Plan for 2016-2020. Quezon City, Philippines: Bureau of Fisheries and Aquatic Resources.

[BFAR] Bureau of Fisheries and Aquatic Resources. 2017. Philippine Fisheries Profile 2017. [Internet]. [cited 2019 Jul 05]. Available from: http://www.bfar.da.gov.ph/publication.

[BFAR] Bureau of Fisheries and Aquatic Resources. 2018. National Tuna Management Plan. Department of Agriculture-Bureau of Fisheries and Aquatic Resources. 92 p.

[BFAR-NFRDI] Bureau of Fisheries and Aquatic Resources-National Fisheries Research and Development Institute. 2012. Western and Central Pacific Fisheries Conservation and Management Measures. Operations Guide for Filipino Fishermen. Department of Agriculture Bureau of Fisheries and Aquatic Resources and National Fisheries Resource Development Institute. $46 \mathrm{p}$.

Bigelow K, Garvilles E, Barut N. 2016. Relative abundance of skipjack for the purse seine fishery operating in the Philippines Moro Gulf (Region 12) and High Seas Pocket \#1. WCPFC Scientific Committee Twelfth Regular Session in Bali, Indonesia; August 3-11, 2016.

Burgaard MG. 2010. Effect of frozen storage temperature on quality-related changes in fish muscle: Changes in physical, chemical, and biochemical quality indicators during short and long term storage. [Internet]. Denmark: 
Technical University of Denmark; [cited 2020 Mar 26]. Available from: https://backend.orbit. dtu.dk/ws/portalfiles/portal/5518000/Thesis_ book.pdf

Dickinson WR. 1973. Japanese Fishing Vessels off Alaska. Marine Fisheries Review 35 (1-2): 6-18.

Diei-Ouadi Y, Mgawe Y. 2011. Post-harvest fish loss assessment in small-scale fisheries: A guide for extension officer. [Internet]. Rome, Italy: FAO Fisheries and Aquaculture Technical Paper No. 559; [cited 2020 Mar 23]. Available from: http://www.fao.org/3/i2241e/i224le.pdf.

Diei-Ouadi Y, Sodoke B, Oduro F, Ouedraogo Y, Bokobosso K, Rosenthal I. 2015. Strengthening the performance of post-harvest systems and regional trade in small-scale fisheries: case study of post-harvest loss reduction in the Volta Basin riparian countries. [Internet]. Rome, Italy: FAO Fisheries and Aquaculture Circular No. 1105; [cited 2020 Mar 25]. Available from: http://www.fao.org/3/a-i5141e.pdf.

Emborg J, Laursen BG, Dalgaard P. 2005. Significant histamine formation in tuna (Thunnus albacares) at 2 degrees $\mathrm{C}$ - effect of vacuumand modified atmosphere- packaging on psychrotolerant bacteria. International Journal of Food Microbiology 101(3): 263-279.

Espejo-Hermes J. 2004. Fish processing technology in the tropics. Quezon City, Philippines. Tawid Publications. 336 p.

[FAO] Food and Agriculture Organization. 1998. Food and Agriculture Organization Fish Utilization and Marketing Service. Responsible fish utilization. [Internet[. Rome: FAO Technical Guidelines for Responsible Fisheries No. 7; [cited 2019 Aug 23]. Available from: http:// www.fao.org/3/w9634e/w9634e00.htm.

Garcia-Tapia G, Barba-Quintero G, Gallegos-Infante JA, Aguilar RP, Ruiz-Cortes JA, Ramirez JA. 2013. Influence of physical damage and freezing on histamine concentration and microbiological quality of yellowfin tuna during processing. Food Science and Technology 33(3): 463-467.
Getu A, Misganaw K, Bazezew M. 2015. Postharvesting and major related problems of fish production. Fisheries and Aquaculture Journal 6(4).

Goulding I. 2001. Refrigerated transport of frozen tuna. INFOPESCA Int. 9. p 27-33.

Havice E, McCoy M, Lewis A. 2019. Market and industry dynamics: Western and Central Pacific Ocean distant water tuna purse seine fishery. Honiara, Solomon Islands. Forum Fisheries Agency. 84 p.

Hipolito Z, Vera CA. 2006. The Philippines Tuna Industry: A Profile. Samudra Monograph. Triannual Report of International Collective in Support of Fishworkers. 69 p.

Johnston WA, Nicholson FJ, Roger A, Stroud GD. 1994. Freezing and Refrigerated Storage in Fisheries. [Internet]. Rome, Italy: FAO Fisheries Technical Paper No. 340; [cited 2019 Aug 23]. Available from: http://www.fao.org/3/v3630e/ V3630E00.htm.

Karningsih PD, Anggrahini D, Kurniati N, Suef M, Fachrur AR, Syahroni N. 2018. Mapping risks of Indonesian tuna supply chain. International Conference on Industrial and System Engineering 337(1): 12-35.

Nair KG. 2002. Handling of Fish Onboard Fishing Vessels. Central Institute of Fisheries Technology. Cochin - 682029.

Nalan G, Pinar Y. 2015. Quality changes of fish during chilling. In: Nalan G, Pinar Y. Seafood Chilling, Refrigeration and Freezing. p 113-127.

[PSA] Philippine Statistics Authority. 2017. Fisheries Statistics of the Philippines. Philippine Statistics Authority. Volume 26 (2015-2017). [Internet]. [cited 2019 Jul 05]. Available from: https://psa.gov.ph/sites/default/files/FSP\%20 2015-2017.pdf

Sampels S. 2014. The effects of storage and preservation technologies on the quality of the products: A review. Journal of Food Processing and Preservation 39(6). 
Shawyer M, Medina-Pizzali A. 2003. The use of ice on small fishing vessels. [Internet]. Rome: FAO Fisheries Technical Paper No. 436; [cited 2020 Mar 26]. Available from: http://www.fao. org/3/a-y5013e.pdf.

Tanangonan I, Demo-os M, Jara J, Ramiscal R. 2018. Group Seine Operations of Philippine Flagged Vessels in High Seas Pocket 1 (HSP-1). Paper presented at WCPFC Scientific Committee Fourteenth Regular Session in Busan, Republic of Korea; August 8-16, 2018.

[USAID] United States Agency for International Development Oceans and Fisheries Partnership. 2017a. Output 1: VCA and CDT Requirements of the Tuna Industry in GSFPC, Philippines. [Internet]. [cited 2020 Mar 23]. Available from: https://www.seafdec-oceanspartnership. org/wp-content/uploads/USAID-Oceans_ Philippines_Output-1_VCA-Report_final.pdf.

[USAID] United States Agency for International Development Oceans and Fisheries Partnership. 2017b. Value Chain Assessment in General Santos City, Philippines. [Internet]. [cited 2020 Mar 25]. Available from: https:// www.seafdec-oceanspartnership.org/wpcontent/uploads/USAID-Combined-ValueChain-Report_Philippines_final.pdf

Vera CA, Hipolito Z, editors. 2006. The Philippines tuna industry: a profile. International Collective in Support of Fishworkers. Chennai, India.
Ward AR, Jeffries DJ. 2000. A Manual for Assessing Post-harvest Fisheries Losses. Chatham, UK: Natural Resources Institute Vii. p 144.

[WCPFC] West and Central Pacific Fisheries Commission. 2012. Conservation and Management Measure for Temporary Extension of CMM 2008-01. Commission Eighth Regular Session in Guam, United States of America; March 26-30, 2012.

[WCPFC] West and Central Pacific Fisheries Commission. 2013. Conservation and Management Measures for Bigeye, Yellowfin, and Skipjack Tuna in the Western and Central Pacific. Conservation and Management Measure 2013-01. Commission Tenth Regular Session in Cairns, Australia; December 2-6, 2013.

[WCPFC] West and Central Pacific Fisheries Commission. 2016a. Annual Report to the Commission, Part 1: Information on Fisheries, Research, and Statistics Committee. Scientific Committee Twelfth Regular Session in Bali, Indonesia; August 3-11, 2016.

[WCPFC] West and Central Pacific Fisheries Commission. 2016b. Conservation and Management Measure for Bigeye, Yellowfin, and Skipjack Tuna in the Western and Central Pacific Ocean. Commission Thirteenth Regular Session in Denarau Island, Fiji; December 5-9, 2016. 22 p. 
Appendix

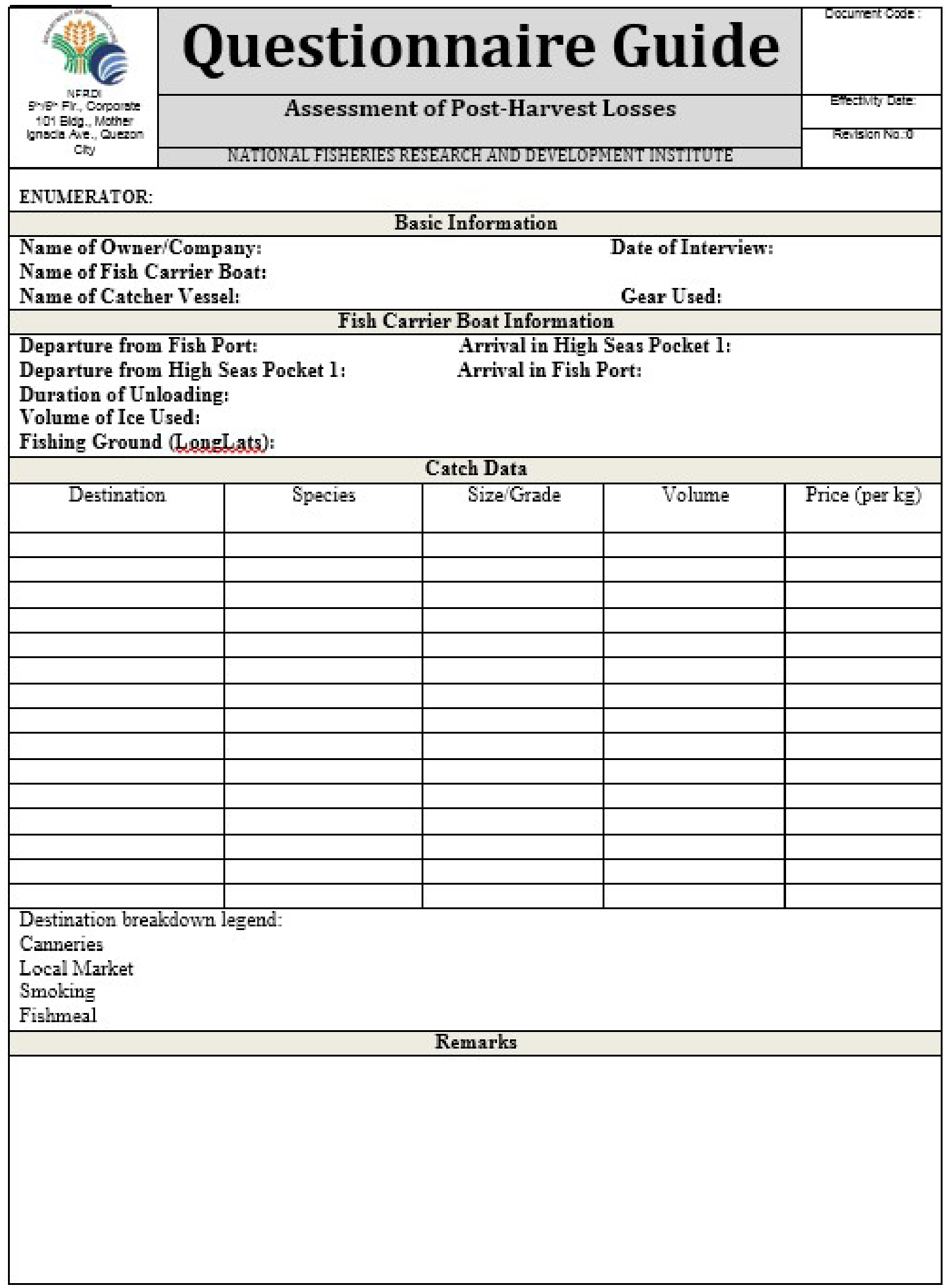

Figure 1. Questionnaire used in assessing post-harvest losses in carrier boats from HSP-1 